\title{
Sistem Pakar Diagnosa Penyakit Infeksi Saluran Pernafasan Akut Pada Anak Menggunakan Teorema Bayes
}

\section{Expert System to Diagnose Acute Respiratory Infection in Children Using the Bayes Theorem}

\author{
Bangkit Sasangka ${ }^{1}$, Arita Witanti ${ }^{2}$ \\ ${ }^{12}$ Program Studi Teknik Informatika, Fakultas Teknologi Informasi, Universitas Mercu Buana Yogyakarta, \\ J1. Wates Km. 10 Yogyakarta 55753, Indonesia \\ Email: 1bangkitsasangka13@gmail.com, ${ }^{2}$ arita@mercubuana-yogya.ac.id
}

\begin{abstract}
ABSTRAK
Infeksi Saluran Pernafasan Akut (ISPA) merupakan penyebab utama morbiditas dan moralitas penyakit menular pada anak-anak. ISPA terutama terjadi di negara-negara dengan pendapatan perkapita rendah dan menengah termasuk Indonesia. Saat ini masih banyak orang tua yang belum mengetahui penyakit khususnya penyakit ISPA yang menimpa pada buah hati mereka. Pada penelitian ini digunakan metode Teorema Bayes. Teorema Bayes adalah teorema yang digunakan dalam statistika untuk menghitung peluang suatu hipotesis. Untuk variabel yang digunakan dalam penghitungan yakni 17 gejala dan 4 penyakit serta bobot-bobot gejala terhadap masing-masing penyakit. Berdasarkan 30 data yang telah diujikan terhadap pakar dan sistem, sistem dapat mendeteksi 4 penyakit yaitu influenza like common, bronkhitis, faringitis dan tonsilitis. untuk pasien yang menderita penyakit ISPA dan sesuai dengan validasi dokter adalah 25 pasien dan yang tidak sesuai adalah 5 pasien. Berdasarkan hasil validasi pakar (dokter) dan sistem, diperoleh akurasi 83,33\% data kasus yang sesuai.
\end{abstract}

Kata Kunci : Anak-anak, ISPA, Teorema Bayes.

\begin{abstract}
Acute Respiratory Infection (ARI) is the main cause of morbidity and morality of infectious diseases in children. ARI mainly occurs in countries with low and middle income per capita, including Indonesia. Currently, there are still many parents who do not know about diseases, especially ARI that infects their children. In this study, the Bayes Theorem method was used. Bayes theorem is the theorem used in statistics to calculate the probability of a hypothesis. The variables used in the calculation were 17 symptoms and 4 diseases as well as symptom weights for each disease. Based on 30 data that have been tested on experts and systems, the system can detect 4 diseases, namely influenza like common, bronchitis, pharyngitis and tonsillitis. For patients suffering from ARI and in accordance with the doctor's validation, there were 25 patients and those who did not match were 5 patients. Based on the validation results of the experts and the system, the accuracy was $83.33 \%$.
\end{abstract}

Keywords: Nä̈ve Bayes, Skull cap, SPK

\section{PENDAHULUAN}

Infeksi Saluran Pernafasan Akut (ISPA) adalah terinfeksinya saluran pernafasan atas maupun disaluran pernafasan bawah yang disebabkan oleh virus, yang sering terjadi pada anak usia 2-5 tahun. Infeksi Saluran Pernafasan Akut (ISPA) disebabkan oleh virus atau bakteri. Penyakit ini diawali dengan panas disertai salah satu atau lebih gejala misalnya tenggorokan sakit atau nyeri telan, pilek, batuk kering atau berdahak. ISPA dihitung dalam kurun waktu 1 bulan terakhir. Lima provinsi dengan ISPA tertinggi adalah Nusa Tenggara Timur $(41,7 \%)$, Papua $(31,1 \%)$, Aceh $(30,0 \%)$, Nusa Tenggara Barat $(28,3 \%)$ dan Jawa Timur $(28,3 \%)$. Proporsi kematian anak yang disebabkan oleh ISPA mencapai 20-30\%. (Depkes, 2008)

Berbagai upaya telah dilakukan oleh pemerintah untuk mengendalikan penyakit ISPA, dimulai sejak tahun 1984 bersamaan dengan diawalinya pengendalian ISPA ditingkat global oleh WHO. Namun sampai saat, upaya tersebut belum memperlihatkan hasik yang signifikan. Kasus ISPA masih 
banyak ditemukan ditempat pelayanan kesehatan, baik tingkat puskesmas maupun ditingkat rumah sakit. Keluarga memiliki peranan penting dalam melakukan upaya pencegahan dan perawatan anak yang menderita ISPA. Hal ini dikarenakan usia anak belum mampu memenuhi kebutuhannya sendiri sehingga membutuhkan bantuan dari orang lain, terutama ibu. Ibu adalah pemberi asuhan primer bagi anak yang sakit kronik. (Kemenkes \& Ditjen, 2012)

Kondisi diatas mendorong munculnya penelitian Sistem Pakar Diagnosa Penyakit Infeksi Saluran Pernafasan Akut Pada Anak Menggunakan Teorema Bayes".

\section{TINJAUAN PUSTAKA \\ 2.1. Tinjauan Pustaka \\ 2.2. Infeksi}

Infeksi merupakan proses invasi dan multiplikasi berbagai mikroorganisme ke dalam tubuh (seperti bakteri, virus, jamur, dan parasit), yang saat dalam keadaan normal, mikroorganisme tersebut tidak terdapat di dalam tubuh. Sebenarnya, di beberapa tempat dalam tubuh kita pun, seperti di dalam mulut atau usus, terdapat banyak mikroorganisme yang hidup secara alamiah dan biasanya tidak menyebabkan infeksi. Namun, dalam beberapa kondisi, beberapa mikroorganisme tersebut juga dapat menyebabkan penyakit. Bakteri, virus, jamur, dan parasit memiliki berbagai cara untuk masuk ke dalam tubuh. Cara penularannya dibagi menjadi kontak langsung dan tidak langsung. Kontak langsung terdiri atas penyebaran orang ke orang (misalnya dari bersin, kontak seksual, atau semacamnya), hewan ke orang (gigitan atau cakaran binatang, kutu dari binatang peliharaan), atau dari ibu hamil ke anaknya yang belum lahir melalui plasenta. Kontak tidak langsung terdiri atas gigitan serangga yang hanya menjadi pembawa dari mikroorganisme atau vektor (seperti nyamuk, lalat, kutu, tungau) dan kontaminasi air atau makanan. Setelah masuk ke dalam tubuh, mikroorganisme tersebut mengakibatkan beberapa perubahan. Mikroorganisme tersebut memperbanyak diri dengan caranya masingmasing dan menyebabkan cedera jaringan dengan berbagai mekanisme yang mereka punya, seperti mengeluarkan toksin, mengganggu DNA sel normal, dan sebagainya. (Zulmiyusrini, 2015)

\subsection{Torema Bayes}

Teorema Bayes adalah teorema yang digunakan dalam statistika untuk menghitung peluang untuk suatu hipotesis. Bayes Optimal Classifier menghitung peluang dari suatu kelas dari masing-masing kelompok atribut yang ada, dan menentukan kelas mana yang paling optimal (Hulaifah, Nasution, \& Anra, 2016).

Dalam teorema bayes langkah awal dari perhitungan yag dilakukan adalah mencari nilai semesta hipotesa $(\mathrm{H})$ yang terdapat pada evidence kemudian dijumlahkan semua nilai probabilitas evidence dari pakar. Untuk langkah - langkah lebih jelasnya dapat dilihat pada Persamaan 2.3 sampai Persamaan 2.7, adalah sebagai berikut :

a. Mencari nilai semesta

$$
\sum_{G}^{P_{1}}=G 01+G 02+G 03+\cdots n
$$

b. Menghitung nilai semesta $\mathrm{P}(\mathrm{Hi})$

$$
\mathrm{P}(\mathrm{H} 1,2, \ldots n)=\frac{H 1,2, \ldots n}{\sum_{k=1}^{p 0}}
$$

c. Menghitung probabilitas $\mathrm{H}$

$$
\sum_{G 0}^{P 0}=P(H) \times P(E \mid H)-n
$$

d. Mencari nilai $\mathrm{P}(\mathrm{Hi} \mid \mathrm{E})$

$$
P(H \mid E)=\frac{P(E \mid H) \times P(H)}{P(H)}
$$

e. Menghitung total nilai bayes

$$
\sum_{R=2}^{P Q} B \quad=B \quad 1+B \quad 2+\cdots n
$$

\subsection{Sistem Pakar}

Sistem pakar adalah sebuah sistem atau sebuah program komputer, yang dirancang untuk memodelkan kemampuan menyelesaikan masalah, seperti peran dari seorang pakar di bidang ilmunya masing - masing. Sistem pakar dibuat dan dikembangkan untuk mempermudah user atau pengguna komputer agar mampu memahami berbagai macam hal yang ingin diketahui, namun user tidak memiliki akses langsung terhadap pakar atau ahli yang memahami tentang keingintahuannya. Sistem pakar sengaja dibuat dan dikembangkan dengan cara mengadopsi pola pikir dan pengetahuan 
manusia (yang dalam hal ini adalah seorang expert atau pakar), yang ditujukan untuk mencari sebuah atau beberapa buah solusi yang memuaskan user-nya seperti ketika seorang pakar atau ahli memberikan penjelasan kepada murid atau penanyaannya. (Dini, 2015)

\section{METODOLOGI PENELITIAN}

Bahan yang digunakan pada sistem pakar diagnosa penyakit infeksi saluran pernafasan akut pada anak dengan metode Teorema Bayes adalah sebagai berikut :

1. Jurnal dan buku yang membahas mengenai penyakit infeksi saluran pernafasan akut, sistem pakar, dan metode teorema bayes.

2. Data hasil wawancara dengan dokter Syarifa di Puskesmas Depok 3 mengenai gejala penentu diagnosa penyakit infeksi saluran pernafasan akut.

3. Data rekam medis pasien sejumlah 30 data yang diperoleh dari Puskesmas Depok 3.

\subsection{Akuisisi Pengetahuan}

Akuisisi pengetahuan merupakan kegiatan untuk mencari dan megumpulkan data untuk analisis kebutuhan perangkat lunak yang bersumber dari seorang pakar.

\subsection{Representasi Pengetahuan}

\subsubsection{Perancangan DFD}

Data Flow Diagram (DFD) merupakan diagram alir data yang menggambarkan bagaimana data di proses oleh sistem. Data Flow Diagram juga menggambarkan notasi aliran data di dalam sistem.

Diagram konteks memiliki sebuah proses untuk penentuan penyakit kulit pada manusia dengan tiga entity yaitu pasien, admin dan user seperti pada Gambar 1

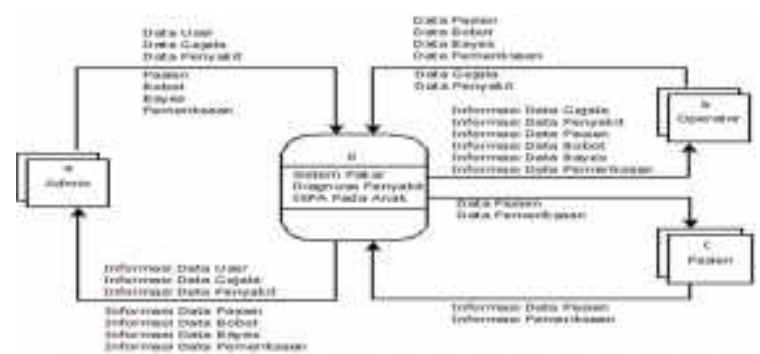

Gambar 1. Diagram Context
DFD level 0 yang merupakan penjabaran dari diagram konteks, dapat dilihat pada Gambar 2.

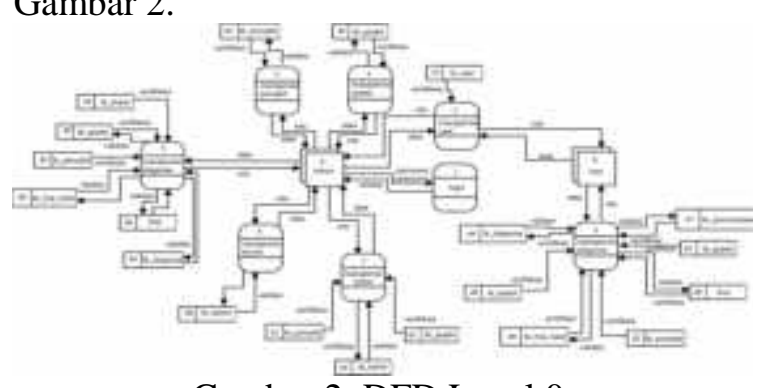

Gambar 2. DFD Level 0.

\subsubsection{Basis Pengetahuan}

Basis pengetahuan dirancang dengan beberapa data yaitu data penyakit, data gejala, data rule, dan bayes, data dapat dilihat pada Tabel 1.

Tabel 1 Data penyakit

\begin{tabular}{cc}
\hline Kode Penyakit & Nama Peyakit \\
\hline PNY01 & $\begin{array}{c}\text { Influenza Like } \\
\text { Common (ILI) }\end{array}$ \\
\hline PNY02 & Bronkhitis \\
\hline PNY03 & Faringitis \\
\hline PNY04 & Tonsilitis \\
\hline
\end{tabular}

Tabel 2. Data Rule

\begin{tabular}{|c|c|}
\hline $\begin{array}{c}\text { Kode } \\
\text { Penyaki }\end{array}$ & Aturan \\
\hline PNY01 & $\begin{array}{l}\text { IF GJ01 AND GJ02 AND GJ03 } \\
\text { GJ04 AND GJ05 AND GJ06 AND } \\
\text { AND GJ10 ANG GJ11 THEN PNY0 }\end{array}$ \\
\hline PNY02 & $\begin{array}{l}\text { IF GJ 01 AND GJ02 AND GJ03 } \\
\text { GJ04 AND GJ 05 AND GJ06 AND } \\
\text { AND GJ13 THEN PNY02 }\end{array}$ \\
\hline PNY03 & $\begin{array}{l}\text { IF GJ01 AND GJ02 AND GJ03 } \\
\text { GJ06 AND GJ07 AND GJ08 AND } \\
\text { AND GJ15 THEN PNY03 }\end{array}$ \\
\hline PNY04 & $\begin{array}{l}\text { IF GJ01 AND GJ02 AND GJ04 } \\
\text { GJ06 AND GJ07 AND GJ08 AND } \\
\text { AND GJ16 AND GJ17 THEN PNY0 }\end{array}$ \\
\hline \multicolumn{2}{|r|}{ Tabel 3. Bayes } \\
\hline No & Teorema Bayes \\
\hline 1. & $0-0.2$ \\
\hline 2. & $0.3-0.4$ \\
\hline 3. & Kemungkinan Besar \\
\hline 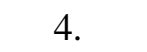 & Hampir Pasti \\
\hline 5. & $0.9-1$ \\
\hline
\end{tabular}


Tabel 4. Data Gejala

\begin{tabular}{|l|l|}
\hline Kode & \multicolumn{2}{|c|}{ Gojala } \\
\hline GJ01 & Demam \\
\hline GJ02 & Batuk-batuk \\
\hline GJ03 & Hidung tersumbat pilek \\
\hline GJ04 & Sakit kepala pusing \\
\hline GJ05 & Sesak nafas mengi \\
\hline GJ06 & Sakit tenggorokan nyeri telan \\
\hline GJ07 & Nafra makan berkarang susah makan \\
\hline GJ08 & Berkurangnya indra pengecap dan ban \\
\hline GJ09 & Tulang dar persendian anggota badan terasa sakit \\
\hline GJ10 & Bintik merah pada tangan telapak tangan \\
\hline GJ11 & Mata berair \\
\hline GJ12 & Meriang dan mengigil \\
\hline GJ13 & Lesulemas (keleiahan) \\
\hline GJ14 & Nyeri telinga \\
\hline GJ15 & Tenggorokan merah dan bengkak \\
\hline GJ16 & Suara serak \\
\hline GJ17 & Warna merah pada amandel (bengkak) \\
\hline
\end{tabular}

\subsubsection{Perancangan Database}

Perancangan database dapat dilihat pada Gambar 3.

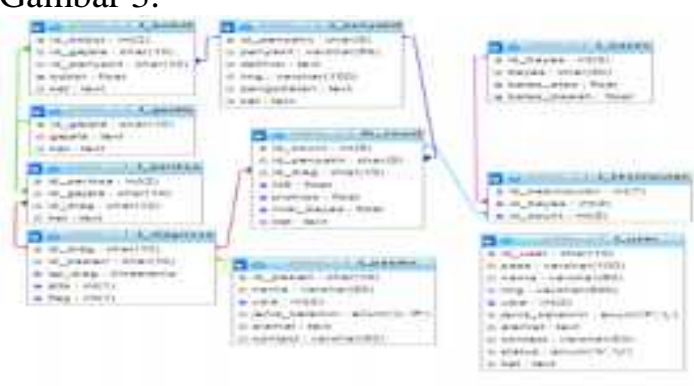

Gambar 3. Database

\subsubsection{Flowchart sistem}

Flowchart sistem dapat dilihat pada Gambar 4

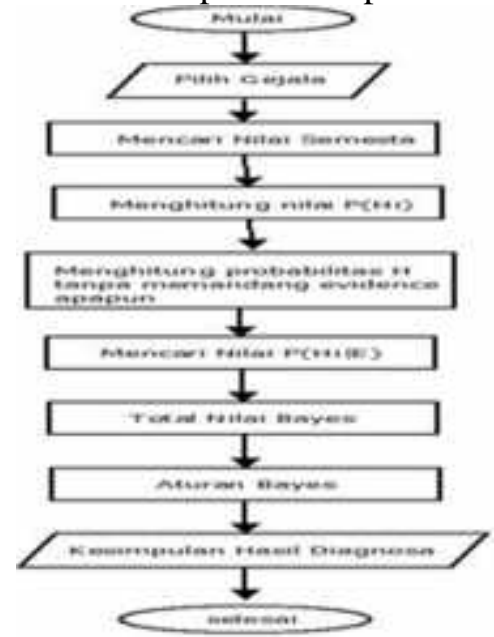

Gambar 4. Flowchart sistem

\section{PEMBAHASAN}

Dalam Perancangan sistem pakar ini menggunakan metode teorema bayes. Teorema bayes dimulai dari mencari nilai semesta total bobot gejala dari tiap penyakit lalu menghitung nilai semesta $\mathrm{P}(\mathrm{Hi})$ di lanjutkan dengan menghitung probalitas $(\mathrm{H})$ tanpa memandang evidence apapun barulah mencari nilai $\mathrm{P}(\mathrm{Hi} \mid \mathrm{E})$ dan langkah terakhir menjumlahkan nilai bayes.

Dalam proses perhitungan teorema bayes pada sistem pakar diagnosa penyakit infeksi saluran pernafasan akut adalah sebagai berikut :

Tabel 5 Sampel data

\begin{tabular}{cccc}
\hline No & $\begin{array}{c}\text { Nama } \\
\text { Pasien }\end{array}$ & Umur & Gejala \\
\hline $\mathbf{1}$ & Pasien & 3 & GJ01, GJ02, \\
& 01 & & GJ04, GJ06, \\
& & & GJ07, GJ15 \& \\
& & & GJ16 \\
\hline
\end{tabular}

Keterangan:

Langkah-langkah perhitungannya adalah sebagai berikut :

a. Step 1 Permasalahan Diketahui daftar penyakit pada Tabel 5

- Rule sistem

- Rule gejala terpilih adalah : GJ01, GJ02, GJ04 \& GJ06 pada PNY01 GJ01, GJ02, GJ04 \& GJ06 pada PNY02 GJ01, GJ02, GJ06, GJ07, GJ15 \& GJ16 pada $\mathrm{PNY} 03$ GJ01, GJ02, GJ04, GJ06, GJ07 \& GJ15 pada PNY04

- Rule Sistem

Rule PNY01 adalah GJ01 AND GJ02

AND GJ03 AND GJ04 AND GJ05

AND GJ06 AND GJ09 AND GJ10

AND GJ11 THAN PNY01.

Rule PNY02 adalah GJ01 AND GJ02

AND GJ03 AND GJ04 AND GJ05

AND GJ06 AND GJ12 AND GJ13

THAN PNY02.

Rule PNY03 adalah GJ01 AND GJ02

AND GJ03 AND GJ06 AND GJ07

AND GJ08 AND GJ16 AND GJ15

THAN PNY03.

Rule PNY04 adalah GJ01 AND GJ02

AND GJ04 AND GJ06 AND GJ07

AND GJ08 AND GJ14 AND GJ16

AND GJ17 THAN PNY04.

- Dimana

GJ01 $=$ Demam

GJ02 = Batuk-batuk 


\author{
GJ04 = Sakit kepala/pusing \\ GJ06 $=$ Sakit tenggorokan/nyeri telan \\ GJ07 = Nafsu makan berkurang/susah \\ makan \\ GJ15 = Nyeri telinga \\ GJ16 = Tenggorokan merah dan \\ bengkak
}

b. Step 3 nilai probabilitas pakar gejala terhadap penyakit.

Nilai probabilitas yang diberikan pakar untuk masing-masing gejala terhadap penyakit.

- nilai probabilitas gejala pada PNY01.

$$
\begin{aligned}
& \text { GJ01 }=0.5 \\
& \text { GJ02 }=0.6 \\
& \text { GJ04 }=0.5 \\
& \text { GJ06 }=0.3
\end{aligned}
$$

- nilai probabilitas gejala pada PNY02.

$$
\text { GJ01 }=0.3
$$

$\mathrm{GJ} 02=0.7$

$\mathrm{GJ} 04=0.7$

GJ06 $=0.5$

- nilai probabilitas gejala pada PNY03.

$$
\begin{aligned}
& \text { GJ01 }=0.6 \\
& \text { GJ02 }=0.7 \\
& \text { GJ06 }=0.7 \\
& \text { GJ07 }=0.3 \\
& \text { GJ15 }=0.8 \\
& \text { GJ16 }=0.8
\end{aligned}
$$

- nilai probabilitas gejala pada PNY04.

$$
\begin{aligned}
& \text { GJ01 }=0.5 \\
& \text { GJ02 }=0.5 \\
& \text { GJ04 }=0.5 \\
& \text { GJ06 }=0.8 \\
& \text { GJ07 }=0.4 \\
& \text { GJ15 }=0.5
\end{aligned}
$$

Langkah perhitungan adalah sebagai berikut :

- GJ01, GJ02, GJ04 \& GJ06 pada rule PNY01.

- Mencari nilai semesta

Nilai Semesta $=0.5+0.6+0.5+0.3$

$$
=1.9
$$

- Menghitung nilai semesta $\mathrm{P}(\mathrm{Hi})$

$$
\begin{aligned}
& \mathrm{P}(\mathrm{H} 1)=0.5 / 1.9=0.263 \\
& \mathrm{P}(\mathrm{H} 2)=0.6 / 1.9=0.312 \\
& \mathrm{P}(\mathrm{H} 3)=0.5 / 1.9=0.263 \\
& \mathrm{P}(\mathrm{H} 4)=0.3 / 1.9=0.157
\end{aligned}
$$

- Menghitung probabilitas $\mathrm{H}$ tanpa memandang evidence apapun

$$
\begin{aligned}
& \mathrm{P}(\mathrm{H} 1) * \mathrm{P}(\mathrm{E} \mid \mathrm{H} 1)=0.263 * 0.5=0.131 \\
& \mathrm{P}(\mathrm{H} 2) * \mathrm{P}(\mathrm{E} \mid \mathrm{H} 2)=0.312 * 0.6=0.187 \\
& \mathrm{P}(\mathrm{H} 3) * \mathrm{P}(\mathrm{E} \mid \mathrm{H} 3)=0.263 * 0.5=0.131 \\
& \mathrm{P}(\mathrm{H} 4) * \mathrm{P}(\mathrm{E} \mid \mathrm{H} 4)=0.157 * 0.3=0.047 \\
& \text { Total Hipotesa }(\mathbf{H}) \quad=\mathbf{0 . 4 9 6}
\end{aligned}
$$

$$
\begin{aligned}
& \text { Mencari nilai } \mathrm{P}(\mathrm{Hi} \mid \mathrm{E}) \\
& \mathrm{P}(\mathrm{H} 1 \mid \mathrm{E})=\left(\mathrm{P}(\mathrm{H} 1)^{*}\right. \\
& \mathrm{P}(\mathrm{E} \mid \mathrm{H} 1) / \mathrm{H}=\left(0.263^{*} 0.5\right) / 0.496=0.265 \\
& \mathrm{P}(\mathrm{H} 2 \mid \mathrm{E})=\left(\mathrm{P}(\mathrm{H} 1)^{*}\right. \\
& \mathrm{P}(\mathrm{E} \mid \mathrm{H} 1) / \mathrm{H}=\left(0.312^{*} 0.6\right) / 0.496=0.377 \\
& \mathrm{P}(\mathrm{H} 3 \mid \mathrm{E})=(\mathrm{P}(\mathrm{H} 1) * \\
& \mathrm{P}(\mathrm{E} \mid \mathrm{H} 1) / \mathrm{H}=\left(0.263^{*} 0.5\right) / 0.496=0.265 \\
& \mathrm{P}(\mathrm{H} 4 \mid \mathrm{E})=(\mathrm{P}(\mathrm{H} 1) * \\
& \mathrm{P}(\mathrm{E} \mid \mathrm{H} 1) / \mathrm{H}=(0.157 * 0.3) / 0.496=0.094 \\
& -\quad \text { Menghitung total nilai bayes } \\
& \text { Nilai Bayes }=(0.5 * 0.265)+(0.6 * 0.377)+ \\
& \quad(0.5 * 0.265)+(0.3 * 0.094) \\
& =0.132+0.226+0.132+0.028 \\
& =0.518
\end{aligned}
$$

Pada GJ01, GJ02, GJ04, dan GJ06 pada rule PNY01 diperoleh nilai 0.518 , jika dicocokkan dengan Tabel aturan bayes maka hasilnya 0.50.7 yang artinya "Kemungkinan Besar".

- GJ01, GJ02, GJ04 \& GJ06 pada rule PNY02.

- Mencari nilai semesta

Nilai Semesta $=0.3+0.7+0.7+0.5$

$$
=2.2
$$

- Menghitung nilai semesta P(Hi)

$\mathrm{P}(\mathrm{H} 1)=0.3 / 2.2=0.136$

$\mathrm{P}(\mathrm{H} 2)=0.7 / 2.2=0.318$

$\mathrm{P}(\mathrm{H} 3)=0.7 / 2.2=0.318$

$\mathrm{P}(\mathrm{H} 4)=0.5 / 2.2=0.227$

- Menghitung probabilitas H tanpa tanpa memandang evidence apapun

$$
\begin{aligned}
& \mathrm{P}(\mathrm{H} 1) * \mathrm{P}(\mathrm{E} \mid \mathrm{H} 1)=0.136 * 0.3=0.040 \\
& \mathrm{P}(\mathrm{H} 2) * \mathrm{P}(\mathrm{E} \mid \mathrm{H} 2)=0.318 * 0.7=0.222 \\
& \mathrm{P}(\mathrm{H} 3) * \mathrm{P}(\mathrm{E} \mid \mathrm{H} 3)=0.318 * 0.7=0.222 \\
& \mathrm{P}(\mathrm{H} 4) * \mathrm{P}(\mathrm{E} \mid \mathrm{H} 4)=0.227 * 0.5=0.113
\end{aligned}
$$

$$
\text { Total Hipotesa }(\mathrm{H}) \quad \mathbf{0} \mathbf{0 . 5 9 7}
$$

- Mencari nilai $\mathrm{P}(\mathrm{Hi} \mid \mathrm{E})$

$\mathrm{P}(\mathrm{H} 1 \mid \mathrm{E})=(\mathrm{P}(\mathrm{H} 1) *$

$\mathrm{P}(\mathrm{E} \mid \mathrm{H} 1) / \mathrm{H}=\left(0.136^{*} 0.3\right) / 0.597=0.067$

$\mathrm{P}(\mathrm{H} 2 \mid \mathrm{E})=(\mathrm{P}(\mathrm{H} 1) *$

$\mathrm{P}(\mathrm{E} \mid \mathrm{H} 1) / \mathrm{H}=\left(0.318^{*} 0.7\right) / 0.597=0.371$

$\mathrm{P}(\mathrm{H} 3 \mid \mathrm{E})=(\mathrm{P}(\mathrm{H} 1) *$

$\mathrm{P}(\mathrm{E} \mid \mathrm{H} 1) / \mathrm{H}=\left(0.318^{*} 0.7\right) / 0.597=0.371$

$\mathrm{P}(\mathrm{H} 4 \mid \mathrm{E})=(\mathrm{P}(\mathrm{H} 1) *$

$\mathrm{P}(\mathrm{E} \mid \mathrm{H} 1) / \mathrm{H}=\left(0.227^{*} 0.5\right) / 0.597=0.189$

- Menghitung total nilai bayes

Nilai Bayes $=(0.3 * 0.067)+(0.7 * 0.371)+$

$$
\begin{aligned}
& (0.7 * 0.371)+(0.5 * 0.189) \\
= & 0.020+0.259+0.259+0.094 \\
= & 0.632
\end{aligned}
$$

Pada GJ01, GJ02, GJ04, dan GJ06 pada rule PNY01 diperoleh nilai 0.632, jika dicocokkan dengan Tabel aturan bayes maka hasilnya 0.50.7 yang artinya "Kemungkinan Besar".

- GJ01, GJ02, GJ06, GJ07, GJ15 \& GJ16 pada rule PNY03. 
- Mencari nilai semesta

Nilai Semesta $=0.6+0.7+0.7+0.3+0.8+0.8$

$$
=3.9
$$

- Menghitung nilai semesta P(Hi)

$$
\begin{aligned}
& \mathrm{P}(\mathrm{H} 1)=0.6 / 3.9=0.153 \\
& \mathrm{P}(\mathrm{H} 2)=0.7 / 3.9=0.179 \\
& \mathrm{P}(\mathrm{H} 3)=0.7 / 3.9=0.179 \\
& \mathrm{P}(\mathrm{H} 4)=0.3 / 3.9=0.076 \\
& \mathrm{P}(\mathrm{H} 5)=0.8 / 3.9=0.205 \\
& \mathrm{P}(\mathrm{H} 6)=0.8 / 3.9=0.205
\end{aligned}
$$

- Menghitung probabilitas H tanpa tanpa memandang evidence apapun

$$
\begin{aligned}
& \mathrm{P}(\mathrm{H} 1) * \mathrm{P}(\mathrm{E} \mid \mathrm{H} 1)=0.153 * 0.6=0.091 \\
& \mathrm{P}(\mathrm{H} 2) * \mathrm{P}(\mathrm{E} \mid \mathrm{H} 2)=0.179 * 0.7=0.125 \\
& \mathrm{P}(\mathrm{H} 3) \mathrm{P}(\mathrm{E} \mid \mathrm{H} 3)=0.179 * 0.7=0.125 \\
& \mathrm{P}(\mathrm{H} 4) * \mathrm{P}(\mathrm{E} \mid \mathrm{H} 4)=0.076 * 0.3=0.022 \\
& \mathrm{P}(\mathrm{H} 5) * \mathrm{P}(\mathrm{E} \mid \mathrm{H} 3)=0.205 * 0.8=0.164 \\
& \mathrm{P}(\mathrm{H} 6) * \mathrm{P}(\mathrm{E} \mid \mathrm{H} 4)=0.205 * 0.8=0.164 \\
& \text { Total Hipotesa }(\mathbf{H}) \quad=\mathbf{0 . 6 9 1}
\end{aligned}
$$

- Mencari nilai $\mathrm{P}(\mathrm{Hi} \mid \mathrm{E})$

$\mathrm{P}(\mathrm{H} 1 \mid \mathrm{E})=(\mathrm{P}(\mathrm{H} 1) *$

$\mathrm{P}(\mathrm{E} \mid \mathrm{H} 1) / \mathrm{H}=\left(0.153^{*} 0.6\right) / 0.691=0.131$

$\mathrm{P}(\mathrm{H} 2 \mid \mathrm{E})=(\mathrm{P}(\mathrm{H} 1) *$

$\mathrm{P}(\mathrm{E} \mid \mathrm{H} 1) / \mathrm{H}=(0.179 * 0.7) / 0.691=0.180$

$\mathrm{P}(\mathrm{H} 3 \mid \mathrm{E})=(\mathrm{P}(\mathrm{H} 1) *$

$\mathrm{P}(\mathrm{E} \mid \mathrm{H} 1) / \mathrm{H}=(0.179 * 0.7) / 0.691=0.180$

$\mathrm{P}(\mathrm{H} 4 \mid \mathrm{E})=(\mathrm{P}(\mathrm{H} 1) *$

$\mathrm{P}(\mathrm{E} \mid \mathrm{H} 1) / \mathrm{H}=\left(0.076^{*} 0.3\right) / 0.691=0.031$

$\mathrm{P}(\mathrm{H} 5 \mid \mathrm{E})=(\mathrm{P}(\mathrm{H} 1) *$

$\mathrm{P}(\mathrm{E} \mid \mathrm{H} 1) / \mathrm{H}=\left(0.205^{*} 0.8\right) / 0.691=0.237$

$\mathrm{P}(\mathrm{H} 6 \mid \mathrm{E})=(\mathrm{P}(\mathrm{H} 1) *$

$\mathrm{P}(\mathrm{E} \mid \mathrm{H} 1) / \mathrm{H}=\left(0.205^{*} 0.8\right) / 0.691=0.237$

- Menghitung total nilai bayes

Nilai Bayes $=(0.6 * 0.131)+(0.7 * 0.180)+$ $(0.7 * 0.180)+(0.3 * 0.031)+(0.8 * 0.237)+$ $(0.8 * 0.237)$

$$
\begin{aligned}
& =0.078+0.126+0.126+0.009+ \\
& \quad 0.189+0.189 \\
& =0.717
\end{aligned}
$$

Pada GJ01, GJ02, GJ06, GJ07, GJ15 dan GJ16 pada rule PNY03 diperoleh nilai 0.717, jika dicocokkan dengan Tabel aturan bayes maka hasilnya 0.7-0.9 yang artinya "Hampir Pasti”.

- GJ01, GJ02, GJ06, GJ07, GJ15 \& GJ16 pada rule PNY04.

- Mencari nilai semesta

Nilai Semesta $=0.5+0.5+0.5+0.8+0.4+0.5$

$$
=3.2
$$

- Menghitung nilai semesta $\mathrm{P}(\mathrm{Hi})$

$\mathrm{P}(\mathrm{H} 1)=0.5 / 3.2=0.156$

$\mathrm{P}(\mathrm{H} 2)=0.5 / 3.2=0.156$

$\mathrm{P}(\mathrm{H} 3)=0.5 / 3.2=0.156$

$\mathrm{P}(\mathrm{H} 4)=0.8 / 3.2=0.25$

$$
\begin{aligned}
& \mathrm{P}(\mathrm{H} 1)=0.4 / 3.2=0.125 \\
& \mathrm{P}(\mathrm{H} 2)=0.5 / 3.2=0.156
\end{aligned}
$$

- Menghitung probabilitas H tanpa tanpa memandang evidence apapun

$\mathrm{P}(\mathrm{H} 1) * \mathrm{P}(\mathrm{E} \mid \mathrm{H} 1)=0.156 * 0.5=0.078$

$\mathrm{P}(\mathrm{H} 2) * \mathrm{P}(\mathrm{E} \mid \mathrm{H} 2)=0.156 * 0.5=0.078$

$\mathrm{P}(\mathrm{H} 3) * \mathrm{P}(\mathrm{E} \mid \mathrm{H} 3)=0.156 * 0.5=0.078$

$\mathrm{P}(\mathrm{H} 4) * \mathrm{P}(\mathrm{E} \mid \mathrm{H} 4)=0.25 * 0.8=0.2$

$\mathrm{P}(\mathrm{H} 5) * \mathrm{P}(\mathrm{E} \mid \mathrm{H} 3)=0.125 * 0.4=0.05$

$\mathrm{P}(\mathrm{H} 6) * \mathrm{P}(\mathrm{E} \mid \mathrm{H} 4)=0.156 * 0.5=0.078$

Total Hipotesa $(\mathrm{H})$

$=0.562$

- Mencari nilai $\mathrm{P}(\mathrm{Hi} \mid \mathrm{E})$

$\mathrm{P}(\mathrm{H} 1 \mid \mathrm{E})=(\mathrm{P}(\mathrm{H} 1) *$

$\mathrm{P}(\mathrm{E} \mid \mathrm{H} 1) / \mathrm{H}=\left(0.156^{*} 0.5\right) / 0.562=0.138$

$\mathrm{P}(\mathrm{H} 2 \mid \mathrm{E})=(\mathrm{P}(\mathrm{H} 1) *$

$\mathrm{P}(\mathrm{E} \mid \mathrm{H} 1) / \mathrm{H}=\left(0.156^{*} 0.5\right) / 0.562=0.138$

$\mathrm{P}(\mathrm{H} 3 \mid \mathrm{E})=(\mathrm{P}(\mathrm{H} 1) *$

$\mathrm{P}(\mathrm{E} \mid \mathrm{H} 1) / \mathrm{H}=\left(0.156^{*} 0.5\right) / 0.562=0.138$

$\mathrm{P}(\mathrm{H} 4 \mid \mathrm{E})=(\mathrm{P}(\mathrm{H} 1) *$

$\mathrm{P}(\mathrm{E} \mid \mathrm{H} 1) / \mathrm{H}=\left(0.25^{*} 0.8\right) / 0.562=0.355$

$\mathrm{P}(\mathrm{H} 5 \mid \mathrm{E})=(\mathrm{P}(\mathrm{H} 1) *$

$\mathrm{P}(\mathrm{E} \mid \mathrm{H} 1) / \mathrm{H}=\left(0.125^{*} 0.4\right) / 0.562=0.088$

$\mathrm{P}(\mathrm{H} 6 \mid \mathrm{E})=(\mathrm{P}(\mathrm{H} 1) *$

\begin{tabular}{|c|c|c|c|}
\hline $\begin{array}{l}\text { Nama } \\
\text { Pasien }\end{array}$ & $\begin{array}{c}\text { Hasil } \\
\text { penyakit }\end{array}$ & $\begin{array}{c}\text { Hasil } \\
\text { hitung }\end{array}$ & $\begin{array}{c}\text { Aturan } \\
\text { inferensi }\end{array}$ \\
\hline Pasien & Influenza & 0.518 & Kemungkinan \\
\hline \multirow[t]{6}{*}{1} & Like & & Besar \\
\hline & Common & & \\
\hline & Bronkhitis & 0.632 & Kemungkinan \\
\hline & & & Besar \\
\hline & Faringitis & 0.717 & $\begin{array}{l}\text { Hampir } \\
\text { pasti }\end{array}$ \\
\hline & Tonsilitis & 0.595 & $\begin{array}{l}\text { Kemungkinan } \\
\text { Besar }\end{array}$ \\
\hline
\end{tabular}

$\mathrm{P}(\mathrm{E} \mid \mathrm{H} 1) / \mathrm{H}=\left(0.156^{*} 0.5\right) / 0.562=0.138$

- Menghitung total nilai bayes

Nilai Bayes $=(0.5 * 0.138)+(0.5 * 0.138)+$ $(0.5 * 0.138)+(0.8 * 0.355)+$ $(0.4 * 0.088)+(0.5 * 0.138)$

$=0.069+0.069+0.069+0.284+$ $0.035+0.069$ $=0.595$

Pada GJ01, GJ02, GJ06, GJ07, GJ15 dan GJ16 pada rule PNY04 diperoleh nilai 0.595 , jika dicocokkan dengan Tabel aturan bayes maka hasilnya 0.5-0.7 yang artinya "Kemungkinan Besar".

Dari hasil perhitungan data sampel pengujian diatas didapat bahwa diagnosa kemungkinan penyakit infeksi saluran penafasan akut pada anak pasien dengan nama Pasien 1 dapat dilihat pada Tabel berikut:

Tabel 6. Hasil Hitung 
Dari Tabel 6 hasil hitung diambil nilai paling tinggi dari setiap gejala terpilih yang dihitung berdasarkan penyakit yang ada, didapatkan bahwa penyakit "FARINGITIS" mendapat nilai paling tinggi yaitu 0.717 , selanjutnya dicocokan dengan Tabel aturan bayes yaitu nilai 0.7-0.8 adalah "Hampir pasti". Maka pasien dengan nama PSN01 didiagnosa menderita penyakit "Faringitis".

\section{KESIMPULAN}

Dari penelitian yang dilakukan, kesimpulan yaitu sistem yang dirancang dengan implementasi metode teorema bayes dapat digunakan untuk membantu dalam diagnosis penyakit infeksi saluran pernafasan akut pada anak, hasil implementasi dapat berjalan sesuai dengan desain, berdasarkan 30 data yang telah diujikan terhadap pakar dan sistem, untuk pasien yang menderita penyakit infeksi saluran pernafasan akut dan sesuai dengan validasi dokter adalah 30 pasien dan yang tidak sesuai adalah 5 pasien. Sehingga untuk tingkat akurasi sistem berdasarkan hasil validasi pakar (dokter) dan sistem, diperoleh presentase $83.33 \%$ data kasus yang sesuai, serta $16.67 \%$ data kasus yang tidak sesuai.

\section{UCAPAN TERIMA KASIH}

Dengan selesainya penelitian penulis ucapakan terima kasih kepada Dokter Syarifah Nur yang telah membantu pembuatan serta memberian data dan bobot untuk sistem pakar infeksi saluran pernafasan aku pada anak di Puskesmas Depok III.

\section{DAFTAR PUSTAKA}

Amborowati, A. (2016, Februari). ANALISIS DAN PERANCANGAN SISTEM PAKAR DIAGNOSA PENYAKIT MEMATIKAN PADA PEREMPUAN MENGGUNAKAN METODE BAYES (Studi Kasus : Asri Medical Center). Seminar Nasional Teknologi Informasi dan Multimedia 2016, 6-7.
Apriana, R. (2013). Perancangan Sistem Pakar Diagnosa Penyakit Paru-Paru pada Anak Forward Chaining dan Backward Chaining. Jurnal INFOTEKMESIN, 2433.

Depkes. (2008). Buku Bagan Manajemen Terpadu Balita Sakit (MTBS). Jakarta.

Dini. (2015, Desember 30). Pengertian Sistem Pakar. Sistem Pakar, hal. 1-3.

Kemenkes, \& Ditjen. (2012). Lihat dan Dengarkan dan Selamatkan Balita Indonesia dari Kematian; Modul Tatalaksana Standar Pneumonia. $P P \& P L$.

Marianti. (2018). Infeksi Saluran Sernapasan Akut (ISPA). ISPA, hal. 1-5.

Mutsaqof, A. A. (2015, Juni). Sistem Pakar Untuk Mendiagnosis Penyakit Infeksi Menggunakan Forward Chaining. JURNAL ITSMART, Vol 4. No 1., 4347.

Octavina dkk. (2014). Sistem Pakar Untuk Mendiagnosa Penyakit Pada Saluran Pernafasan dan Paru Menggunakan Metode Certainty Factor. Jurnal Sarjana Teknik Informatika, 11231132.

Samsudin. (2017). Aplikasi Sistem Pakar Diagnosa Penyakit Pernafasan Menggunakan Metode Case-Based Reasoning. JURNAL IPTEKS TERAPAN, 272-282.

Zulmiyusrini, P. (2015, Februari 07). Definisi Infeksi. Infeksi, hal. 1-4.

Zunaidi, M. (2017). Penerapan Sistem Pakar Untuk Mendeteksi Penyakit Infeksi Saluran Pernafasan Dengan Metode Dempster Shafer. Jurnal Ilmiah Saintikom, 163-171. 